\title{
Conservation status assessment of aquatic habitats within the Rhine floodplain using an index based on macrophytes
}

\author{
M. Trémolières ${ }^{1 *}$, I. Combroux ${ }^{1}$, A. Herrmann ${ }^{2}$, P. Nobelis ${ }^{3}$ \\ ${ }^{1}$ CEVH UMR MA 101 ULP/ENGEES, Institute of Botany 28 rue Goethe F-67083 Strasbourg, France \\ ${ }^{2}$ ENGEES, 1 quai Koch F-67083 Strasbourg, France \\ ${ }^{3}$ Institut de Recherche Mathématique Avancée (IRMA), 7 rue René Descartes F-67084 Strasbourg, France
}

\begin{abstract}
The programme LIFE Nature "Conservation and restoration of habitats of the Rhine fringe" (2002-2005) focussed on the assessment of the conservation status of terrestrial and aquatic habitats. Along the Rhine fringe, the degree of connection between waterbodies and the river main channel determined the water flow (surface or phreatic waters, flow velocity) and induced flood disturbances (hydromorphological quality, scouring effect). A new typology based on metrics characterizing the conservation status, was proposed for the upper Rhine floodplain. Seven physical and biological metrics were selected: specific richness, presence or absence of rare, polluto-tolerant and exotic species, species abundance, degree of connection, and trophy level defined by the macrophyte community. Aquatic macrophytes surveys were conducted at 315 sites along the Rhine French fringe. Multiple correspondence analysis and discriminant analysis were used to define metrics scores in a preliminary network of 129 macrophytes surveys stands. Metrics were combined to give a measure of the conservation status of the 315 sites. Five classes of the conservation status have been defined from degraded to excellent status. The mapping of the conservation status was realized to answer the question addressed by the program "Life Nature". We discuss on the choice of the metrics and their justification in the definition of the conservation status. The method was tested in the fluvial hydrosystem of Ill river, the main tributary of the Rhine river in the Alsace floodplain, and compared to the French trophic index based on macrophytes, IBMR.
\end{abstract}

Keywords: biological index, conservation status, macrophytes, running waters, Rhine floodplain

\section{Introduction}

In aquatic systems, both running and standing waters, high physical (current velocity, substrate, light...) and chemical (organic matter and nutrient content) fluctuations were commonly observed (Dodkins et al. 2005). Although they show high ecological plasticity, species and plant communities cope with these fluctuations (Barrett et al. 1993, Garbey et al. 2003). Thus their use as bioindicators can be discussed due to their high adaptability in changing environment. Bioindication is based on the tolerance of certain species to high levels of mineral nutrients or organic pollution and conversely to a high sensitivity to pollution or adaptation to low level of nutrient of others. Affected waters will tend to support an increased abundance of more nutrient-tolerant species associated with an overall loss of species diversity.

Nowadays, macrophytes are commonly used as indicators of the nutrient status and their use lead to the proposal of numerous European typologies (Grasmück 1995,

\footnotetext{
* Corresponding author :

E-mail : michele.tremolieres@bota-ulp.u-strasbg.fr
}

Robach et al. 1996) or indices (MTR Mean Trophic Rank of Holmes 1995, RPM Relative Pflanzen Menge of Kohler \& Janauer 1995, TIM Trophic Index of Macrophytes of Schneider \& Melzer 2003, IBMR Indice Biologique Macrophytes en Rivière in France 2003, Haury et al. 2006).

Aquatic systems are more and more considerably altered by organic pollution and then become eutrophic, and sometimes hypertrophic depending on the phosphorus content (SRP) and nitrogen, as a consequence of degradation of organic matter. A 'damage rate' based on macrophytes community relative to an undisturbed reference was proposed by Haslam (1982). Recently, the Water Framework Directive (WFD 2000, transposed in France 2004) required the good ecological status of surface waters to be reached, and the reduction in the release of dangerous and toxic substances. Application of WFD needs (1) to find indicators to estimate ecological quality (e.g. structure and function of habitats) based on physical, chemical and biological quality of water bodies and (2) to establish a reference system. In another hand, the Habitats (Natura 2000) Directive focussed on the definition of conservation status of habitats and species. In the Alsace 
Rhine floodplain (Eastern France), the program LIFE Nature "conservation and restoration of habitats" (20032005), aimed (1) the definition of a reference for a good conservation status of habitats (terrestrial and aquatic habitats according to the Natura 2000 definition) and (2) mapping of this status in order to identify sites or stretches to preserve, restore or rehabilitate.

A bioindication scale of eutrophication based on macrophyte communities was established in the phreatic streams of the Alsace floodplain, a scale which covered the whole gradient of trophy level, from oligotrophic to eutrophic (Carbiener et al. 1990, Robach et al. 1996) as that formerly proposed by Kohler (1975). At each trophy level, corresponded a plant community (defined by the phytosociological method according to Braun-Blanquet 1964). However, this method was not validated neither for standing waters (lakes, ponds) nor for marshes habitats; it defined more precisely a trophic level than a conservation status.

To assess the conservation status of water bodies of the Rhine fringe (as defined in the programme LIFE), both running (streams, connected lateral arms) as standing waters (cut-off channels, ponds, marshes), we proposed a new tool based on macrophytes. This tool was set-up in the former lateral arms of the Rhine, in order to identify sectors exhibiting good and bad conservation status and specify the ones that could be restored.

\section{Methodology}

Three steps were used 1) vegetation sampling and identification of the plant community, 2) definition of the conservation status through a notation based on 7 metrics, and 3) mapping of the conservation status of aquatic habitats of the Rhine fringe.

\section{Study sites}

The upper Rhine floodplain was drastically managed until the $19^{\text {th }}$ century, by straightening and canalisation. As a consequence, many water bodies were cut-off from the river Rhine. Both hydrological connection and exchange between river and water bodies and exchange with the groundwater were highly modified by the hydraulic management of the river. However, some indirect hydrological relationships, i.e. seepage from the river to the groundwater were preserved and thus influenced the water quality of disconnected former lateral arms which were still supplied by groundwater. The water nutrient content of water bodies along the river fringe, depends on the type and degree of connection with the river main channel (Trémolières et al.1993, Eglin et al.1997, Bornette et al.1998). The water bodies which are supplied by surface water (Rhine waters) are eutrophic, whereas the disconnected ones are most of the time mesotrophic. Where water is supplied by a mixture of ground- and surface-water, waterbodies can be mesotrophic to eutrophic, depending on the surface water quality.

In the Alsace floodplain (Eastern France), along the Rhine fringe, we selected aquatic sites or stretches belonging to the five aquatic habitat types according to Natura 2000 classification (Table 1, Bensettiti et al. 2002). Study sites were composed of water bodies, 50 to $100 \mathrm{~m}$ length in running waters and $10 \mathrm{~m}^{2}$ minimal surface in standing waters.

Table 1. Definition of the five aquatic natural habitat types whose conservation requires designation of Natura 2000 sites present in the Rhine fringe

\begin{tabular}{|c|l|}
\hline Natura 2000 Codes & Characteristics, phytosociological name \\
\hline 3130 & $\begin{array}{l}\text { Oligotrophic to mesotrophic standing waters with } \\
\text { vegetation of the Littorelletea uniflorae } \text { and/or of the } \\
\text { Isoëto-Nanojuncetea }\end{array}$ \\
\hline 3140 & $\begin{array}{l}\text { Hard oligo-mesotrophic waters with benthic } \\
\text { vegetation of Chara spp. }\end{array}$ \\
\hline 3150 & $\begin{array}{l}\text { Natural eutrophic lakes with Magnopotamion or } \\
\text { Hydrocharition - type vegetation }\end{array}$ \\
\hline 3260 & $\begin{array}{l}\text { Water courses of plain to montane levels with the } \\
\text { Ranunculion fluitantis } \text { andCallitricho-Batrachion } \\
\text { vegetation }\end{array}$ \\
\hline 3270 & $\begin{array}{l}\text { Rivers with muddy banks with Chenopodion rubri } \\
\text { p.p. and Bidention p.p. vegetation }\end{array}$ \\
\hline
\end{tabular}

\section{Vegetation sampling}

Macrophyte surveys $(\mathrm{N}=315)$ were carried out between mid-June and mid-September, according to the phytosociological method of Braun-Blanquet (1964). Vascular plants and bryophytes were identified to the species level, whereas algae were identified to the genus level. According to this macrophyte survey, we designated a community according to Oberdorfer (1992) and the trophy scale proposed for the Rhine floodplain by Robach et al. (1996). This latest scale identified six communities named A to F, corresponding to a gradient of trophy, from oligotrophic to eutrophic level.

Each survey was characterized by a phytosociological community and a 'trophic' community coded in the Table 2. 
Table 2. Correspondence between phytosociological community, trophic community and Natura 2000 habitat code, and number of surveys per community used in the statistical analyses with the proposed conservation status. $\mathrm{N}=$ total number of surveys; *according to Oberdorfer (1992), **according to Robach et al. (1996)

\begin{tabular}{|c|c|c|c|c|c|}
\hline $\mathrm{N}$ & $\begin{array}{c}\text { Conservation } \\
\text { status }\end{array}$ & Code & $\begin{array}{c}\text { Phytosociological community } \\
\text { or alliance* }\end{array}$ & $\begin{array}{l}\text { Community in the } \\
\text { trophic scale** }\end{array}$ & $\begin{array}{l}\text { Habitat code } \\
\text { (Natura 2000) }\end{array}$ \\
\hline 56 & & calo & Callitrichetum obtusangulae & $\mathrm{C}$ & 3260,3150 \\
\hline 26 & & cerd & Ceratophylletum demersi & $\mathrm{E}$ & 3260,3150 \\
\hline 13 & good & char & Charion & $\mathrm{C}$ & 3140 \\
\hline 59 & & elod & Elodeetum & $\mathrm{E}$ & 3260,3150 \\
\hline 15 & moderate & lemt & Lemnetum trisulcae & $\mathrm{C}$ & 3260,3150 \\
\hline 20 & & $\operatorname{lmsp}$ & $\begin{array}{c}\text { Lemno minoris- Spirodeletum } \\
\text { polyrrhizae }\end{array}$ & $\mathrm{E}$ & 3150 \\
\hline 1 & high & myri & Myriophyllo-Nupharetum & $\mathrm{C}$ & 3150 \\
\hline 25 & & potl & Potamogetonetum lucentis & $\mathrm{D}$ & 3150 \\
\hline 63 & poor & potp & Potamogetonetum pectinati & $\mathrm{E}$ & 3260,3150 \\
\hline 37 & bad & ranf & Ranunculetum fluitantis & $\mathrm{F}$ & 3260 \\
\hline
\end{tabular}

\section{Definition of the metrics}

Seven metrics were defined for the 315 surveys. Five simple ecological metrics were proposed to assess the conservation status:

(1) specific richness with four modalities : $1=0-4$, $2=5-7,3=7-10,4=11-23$.

(2) presence of rare species. They were the species of the regional red list such as Sparganium minimum, Potamogeton trichoïdes, P. Friesii, and two less frequent species Nymphea alba and Najas marina.

(3) presence of polluto-tolerant species. Species considered as polluto-tolerant which grow in the Alsace floodplain were Potamogeton pectinatus, Ranunculus fluitans, Potamogeton nodosus, and Lemna gibba.

(4) presence of exotic species (Elodea sp.).

(5) vegetation cover percentage with 4 modalities : $1=0-30 \%, 2=30-60 \%, 3=60-80 \%, 4=80-100 \%$.

The classes of specific richness and cover were defined as medians and quartiles of these variables.

Two additional physical and chemical metrics were used:

(1) connection, that involves fluxes of material (nutrient and sediments) and living organisms, occurs both between cut-off channels and main channel, and between channels and groundwater. Three modalities were considered for the degree of connection: 1 = very high (permanent connections), 2 = intermediate (depending on frequency and magnitude of floods) and $3=$ very low (infrequent connections).

(2) trophy level with 3 modalities: mesotrophic, eutrophic, hypertrophic. This metric was obtained from the plant community survey according to the bioindication scale (Robach et al. 1996), independently from the degree of connection.

We selected 129 surveys, representing the 5 phytosociological communities which status was known according to experts opinion (ranging from good to bad) in order to calibrate the measure of conservation status (Table 2). Then, the index of the conservation status was calculated for the remaining 186 surveys representing five other phytosociological communities. Conservation status of these sites were not defined $a$ priori. The index of conservation defined for a set of 619 surveys (including the 315 surveys) located along the Rhine fringe was mapped with a GIS (Geographical Information System- geoconcept software).

\section{Statistical analyses}

The data used in this analysis was obtained from surveys of 315 aquatic sites, along the upper Rhine left bank. This set was analysed by using the SAS software (Version 9.1, 2002-2004, SAS Institute Inc., Cary, NC, USA). 
Physical and biological data were coded into classes. We obtained a numerical representation of each site by projection on the first two principal axes through a multiple correspondence analysis (MCA) used in case of qualitative data (Greenacre 1984). This step allows us to transform mixed data (qualitative and quantitative) in normalized numerical data. The first two principal axes explain $30.47 \%$ of inertia which can be estimated to be sufficient to classify sites into classes of conservation status.

A canonical discriminant analysis (CDA) was then applied on transformed data (Hand 1981). By this way a linear function of the two principal components was built in order to classify the 129 calibration surveys into communities of known conservation status. A single linear function is sufficient in the case of two components. This linear function gives a score for each modality of coded data. So we are able to classify a site by using the coding of the first step. This procedure was used to classify the 186 supplementary test surveys and to validate the first classification.

\section{Results}

\section{Floristic composition of habitats}

At first we observe an unequal distribution of Natura 2000 habitats in the Rhine fringe: habitats 3130 and 3270 are present in less than $1 \%$ of waterbodies, habitat 3140 in less than $7 \%$ and habitats 3150 and 3260 are the most common habitats with approximatively $45 \%$ of the whole studied stations. Habitats 3130 and 3270 are colonised by helophytic vegetation with preference for the bank and the zone of tidal range. Habitat 3140 with Characean occurs in recently opened habitats with clear waters.

Ten phytosociological communities of hydrophytes (named according to Oberdorfer 1992) are found in the three aquatic habitats of running waters (3260), standing waters (3150) and Characean habitat (3140). Fourteen phytosociological communities are found in total in the Rhine fringe whether we include marsh habitats (3170 and 3230). All these communities correspond to the mesotrophic and eutrophic levels: C, D and $\mathrm{E}$ in the scale of bioindication (Robach et al. 1996) (table 2). In the connected sectors, four phytosociological communities were found: Ranunculetum fluitantis and Potamogetonetum pectinati in running waters, and $\mathrm{Ce}$ ratophylletum demersi, Potamogetonetum lucentis and again Potamogetonetum pectinati in standing waters. These four communities are the richest with up to around 30 species and correspond to eutrophic $\mathrm{D}$ and $\mathrm{E}$ communities in the bioindication scale. In the discon- nected sectors, the growing vegetation is dominated by Callitriche obtusangula, Berula erecta and Lemna trisulca. These species defined two communities: the Callitrichetum obtusangulae and the Lemnetum trisulcae. These two communities are attributed to the mesotrophic $\mathrm{C}$ community in the bioindication scale (Robach et al. 1996). In oligotrophic conditions (rarely found in the Rhine fringe), the Myriophyllo-Nupharetum with Myriophyllum verticillatum and Nymphea $a l b a$, as characteristic species, is growing in standing waters. The new area opened by the reconnection to the river main channel are often colonised in mesotrophic conditions by pioneer Characean or by exotic species such as Elodea nuttallii in more eutrophic conditions.

\section{Distribution of communities according to their conservation status}

The distribution of macrophyte communities within the Alsace floodplain exhibits a characteristic pattern as shown by the multivariate analysis in Fig. 1: the first axis of the factorial plan (MCA) is strongly associated with the trophic gradient: hypertrophic level and the presence of polluto-tolerant species are associated with negative values, whereas the presence of rare species is associated with positive values on axis 1 . Figure 2 showed the distribution of communities, whose conservation status is already known, in the factorial plan $\mathrm{F} 1 \mathrm{xF} 2$ of the discriminant analysis. The first axis, representing trophic gradient, can be considered as an ecological gradient, high values of conservation status representing a good status. All the sites with the communities of good conservation status are located towards the positive values of F1 axis and the communities of a less good quality presented negative values. The Myriophyllo-Nupharetum (Myri) community, exhibiting the highest value on the first axis, was characterized by the presence of rare species such as Nymphea alba, and the absence of polluto-tolerant species in an oligotrophic water. The Lemnetum trisulcae (Lemn) characterized a "moderate" conservation status with mesotrophic water, medium specific richness, around 7 species and the absence of polluto-tolerant and exotic species. On the opposite way, the Ranunculetum fluitantis (Ranf) and the Potamogetonetum pectinati (Popt) communities present both polluto-tolerant and exotic species. So, they are in a poor to bad conservation status with a high trophic level. Figure 3 showed a factorial plan F1xF2 with the 186 supplementary individual surveys. The mesotrophic community Callitrichetum (Calo) had positive values on the axis 1 and the eutrophic community Potamogetonetum lucentis (Potl) negative values, confirming the first axis as a trophic gradient. 


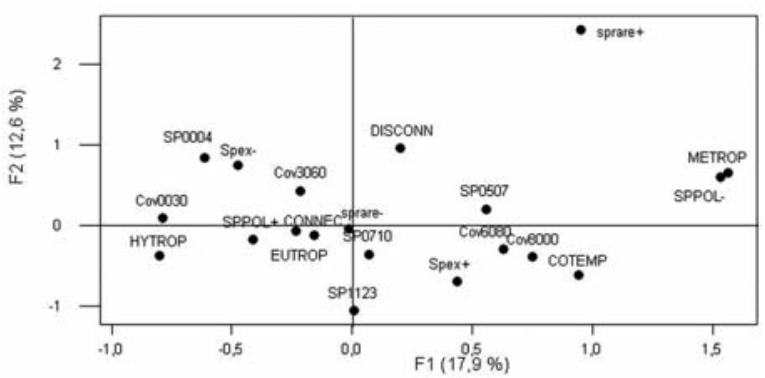

Fig. 1. Distribution of modalities of metrics in the Factorial plan F1xF2 (MCA Multiple Correspondence Analysis). Specific richness : SP0004: 0 - 4 species, SP0507: 5 - 7 species, SP0710: 7 10 species, SP1123: 11 - 23 species; rare species : presence sprare+, absent :sprare-; polluto-tolerant species : presence, SPPOL+, absent , SPPOL- ; exotic species : present, Spex+, absent, Spex- ; cover : 0 - 30\%, Cov0030, 30 - 60\%, Cov3060, 60 $80 \%$, Cov6080, $80-100 \%$, Cov8000 ; Connection : connected, CONNEC, temporarily connected, COTEMP, disconnected, DISCONN ; Trophic level : mesotrophic, METROP, eutrophic, EUTROP, hypertrophic, HYTROP.
Table 3. Scores of modalities of the metrics for the definition of the conservation status

\begin{tabular}{|c|c|c|c|}
\hline Metrics & Modalities & Value & $\begin{array}{l}\text { Myriophyllo- } \\
\text { Nupharetum }\end{array}$ \\
\hline Specific richness & $\begin{array}{l}0-4 \\
5-7 \\
7=10 \\
11-23\end{array}$ & $\begin{array}{l}-0.13 \\
0.72 \\
-0.14 \\
-0.65\end{array}$ & -0.65 \\
\hline Rare species & $\begin{array}{l}\text { Presence } \\
\text { Absence }\end{array}$ & $\begin{array}{r}2.52 \\
-0.04 \\
\end{array}$ & 2.52 \\
\hline Polluto-tolerant species & $\begin{array}{l}\text { Presence } \\
\text { Absence }\end{array}$ & $\begin{array}{l}-0.55 \\
2.08\end{array}$ & 2.08 \\
\hline Exotic species & $\begin{array}{l}\text { Presence } \\
\text { Absence }\end{array}$ & $\begin{array}{c}0.04 \\
-0.04\end{array}$ & -0.04 \\
\hline$\%$ of cover & $\begin{array}{l}0-30 \% \\
30-60 \% \\
60-80 \% \\
80-100 \%\end{array}$ & $\begin{array}{l}-0.78 \\
0.04 \\
0.49 \\
0.56\end{array}$ & 0.56 \\
\hline \multirow[t]{2}{*}{ connection } & $\begin{array}{l}\text { connected } \\
\text { Temporarily } \\
\text { connected }\end{array}$ & $\begin{array}{l}-0.24 \\
0.62\end{array}$ & \\
\hline & disconnected & 0.81 & 0.81 \\
\hline Trophy & $\begin{array}{l}\text { mesotrophic } \\
\text { eutrophic } \\
\text { hypertrophic }\end{array}$ & $\begin{array}{l}2.01 \\
-0.29 \\
-1.08\end{array}$ & 2.01 \\
\hline $\begin{array}{l}\text { Index of conservation } \\
\text { status }\end{array}$ & & & 7.29 \\
\hline
\end{tabular}

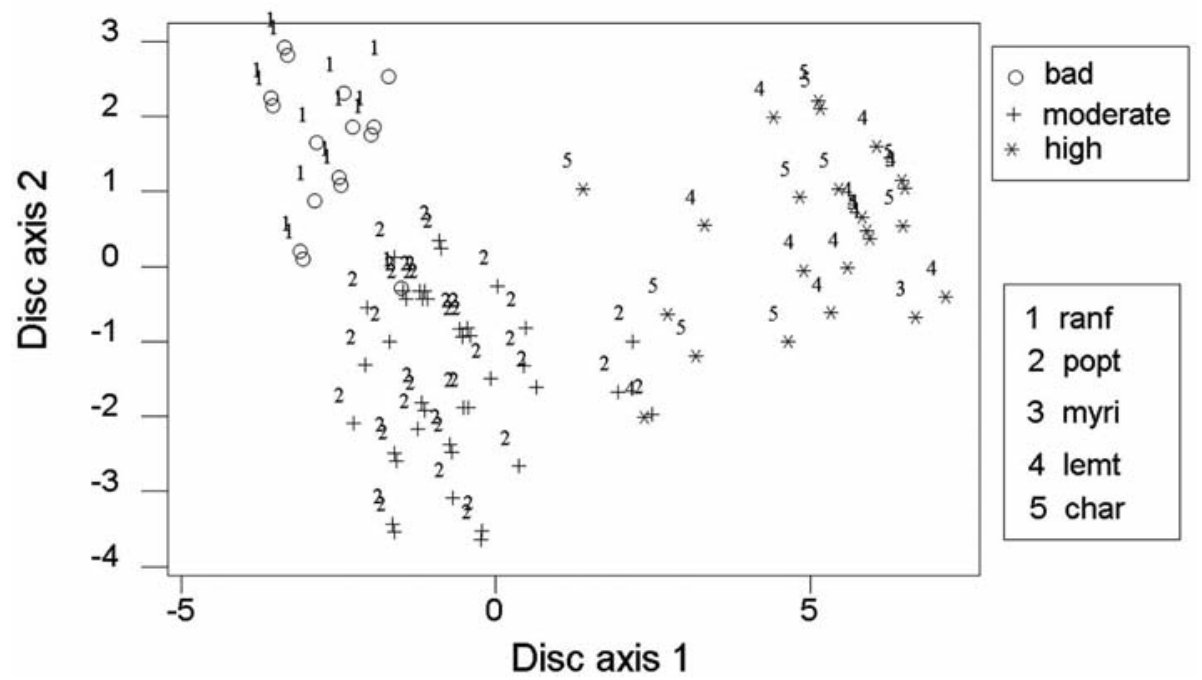

Fig. 2. Distribution of the 5 plant communities classified according to their conservation status on the factorial plan F1xF2 (CDA Canonical Discriminant Analysis). The code of community is given in the table 2 .

The coordinate on the first axis in the discriminant analysis (main discriminatory axis) of each modality of the metrics was used as a score (Table 3). All the scores corresponding to the modality of the survey under study were added to calculate an index for the survey (see the example of the community Myriophyllo-Nupharetum, Table 3). Classes were determined according to the classification of the individuals of the 5 known communities : $>6$ very good conservation state (high), 3-6 good, 1-3 moderate, 1 to -2 poor, $<-2$ bad. The extreme values corresponded respectively to the communities Potamogetonetum pectinati (Potp) in a poor status and Charetum (Char) in a good status (Fig. 3). Callitrichetum and Lemnetum trisulcae were in moderate status.

\section{Application to the fluvial system of the Ill river}

The classification of conservation status proposed in this study was tested in a system close to the Rhine fringe, the ILL river which is the main tributary of the Rhine in the Alsace floodplain. The system studied 


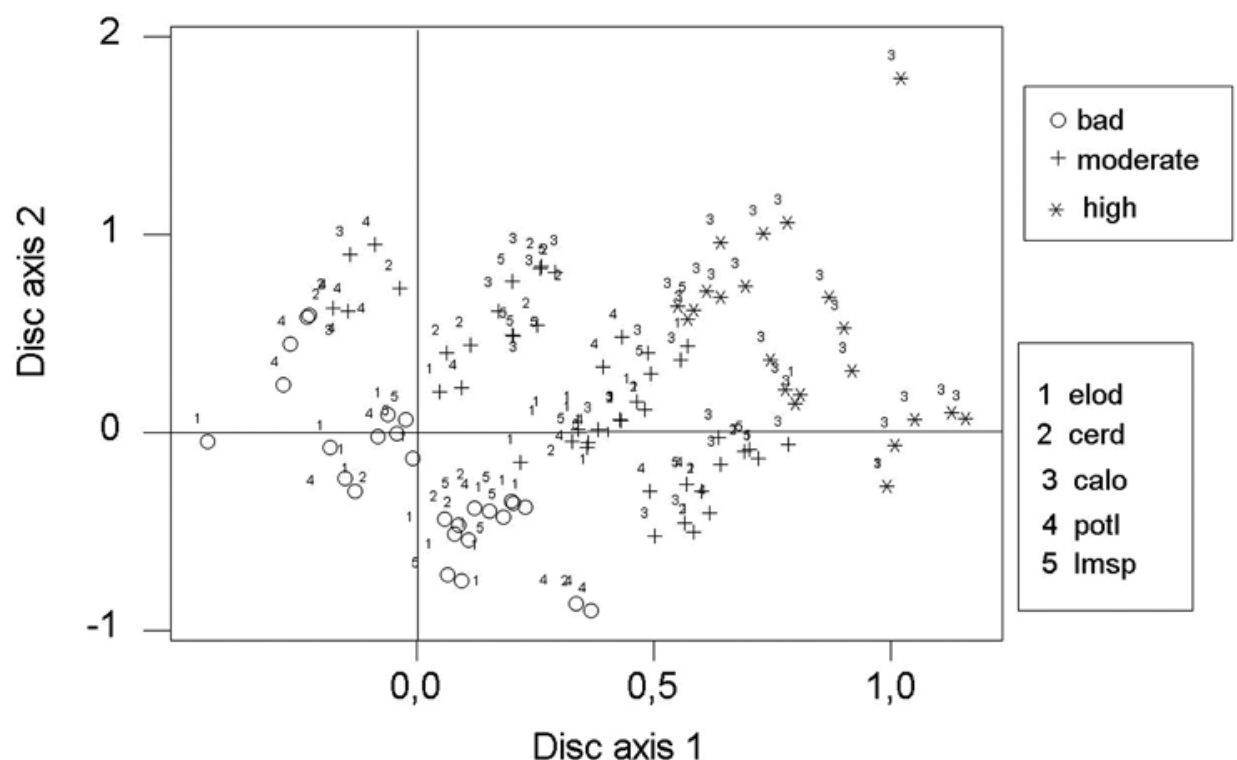

Fig. 3. Distribution of 5 supplementary plant communities (not classified) in the factorial plan F1xF2 (CDA Canonical Discriminant Analysis). The code of community is given in the table 2.

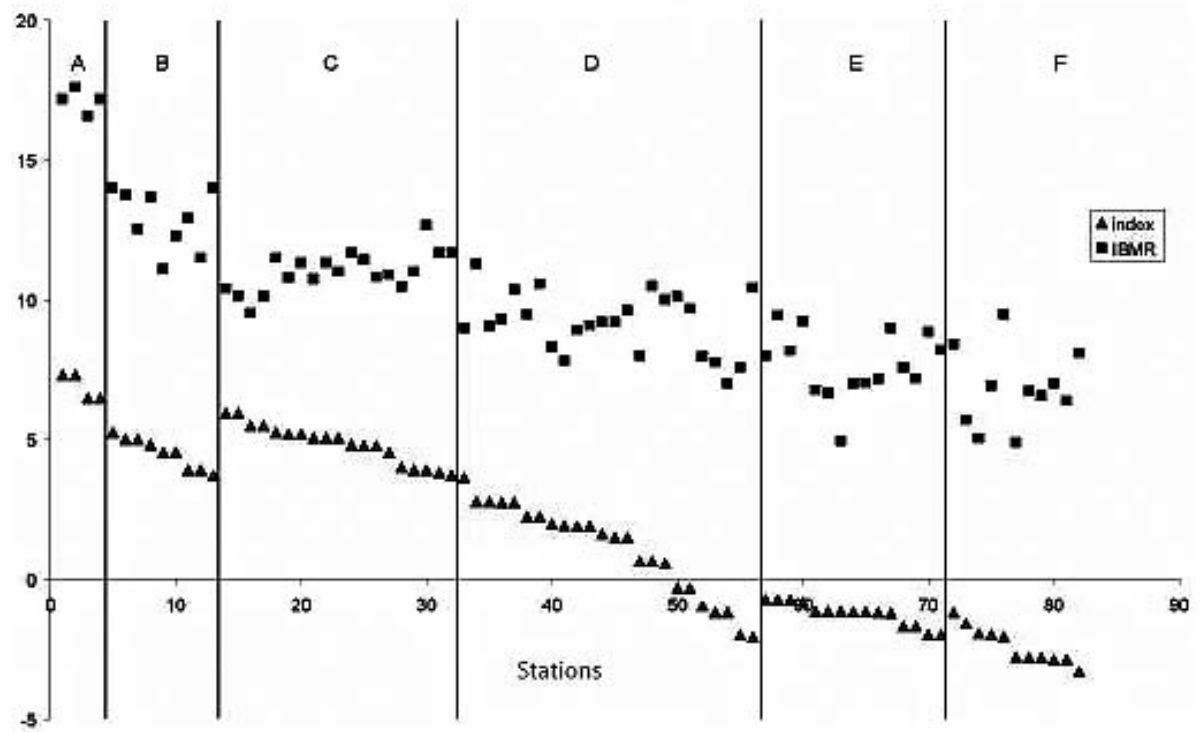

Fig. 4. Correspondence between communities of the trophic scale (named A,B,C,D,E,F from oligotrophic to eutrophic level), IBMR (Biological Macrophyte Index in River, AFNOR 2003) and index of conservation status in the hydrological network of the ILL floodplain (Eastern France).

concerns a flooded forest of the ILL, through which flows a large hydrological network $(52 \mathrm{~km}$ in a forested surface of 1500 ha). This network encompasses connected, disconnected streams still fed by groundwater, and streams temporarily connected by floods. In this sector, there is no seepage of ILL waters into the groundwater (Trémolières et al. 1994). So the disconnected streams fed by groundwater are either oligotrophic, characterized by a plant community with Potamogeton coloratus, a species characteristic of a very low trophy level, or oligo mesotrophic, with a single species Berula erecta. 

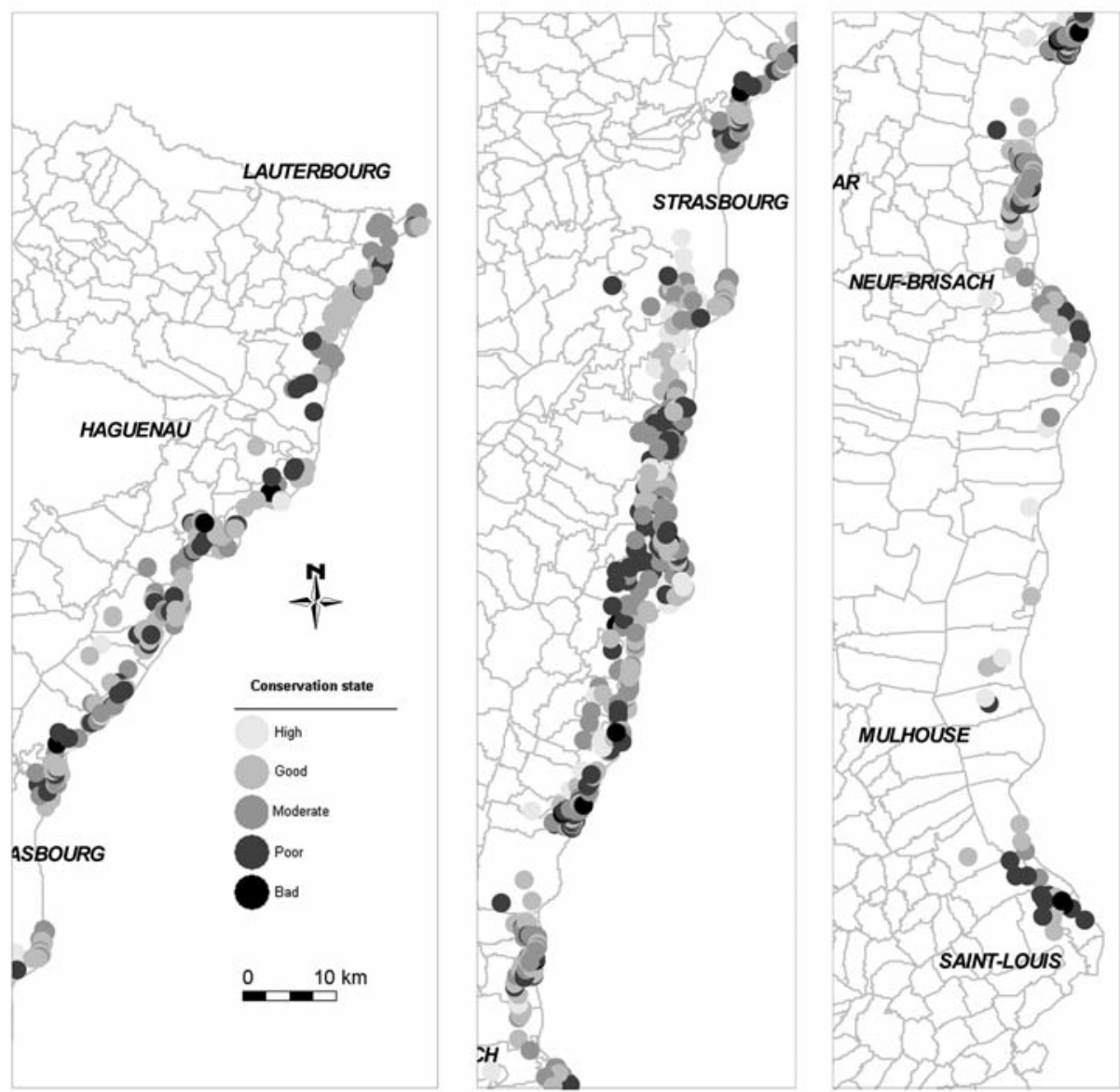

Fig. 5. Mapping of the conservation status of aquatic habitats in the Rhine fringe based on the conservation index.

Table 4. Correspondence between IBMR (Biological Macrophyte Index in River, AFNOR 2003) and conservation status index in the streams of Ill floodplain. In brackets: number of surveys.

\begin{tabular}{|l|c|c|c|c|c|c|}
\hline Community & \multicolumn{1}{|l|}{$\mathrm{A}(4)$} & \multicolumn{1}{l|}{$\mathrm{B}(9)$} & $\mathrm{l}(19)$ & $\mathrm{D}(24)$ & $\mathrm{E}(15)$ & $\mathrm{F}(11)$ \\
\hline IBMR & 17.1 & 12.8 & 11 & 9,2 & 7.7 & 6.8 \\
\hline std & 0.42 & 1.08 & 0.7 & 1.1 & 1.2 & 1.7 \\
\hline $\begin{array}{l}\text { Index of } \\
\text { conservation } \\
\text { status }\end{array}$ & 6.9 & 4.5 & 4.8 & 1.05 & -1.24 & -2.38 \\
\hline Std (index) & 0.47 & 0.55 & 0.69 & 1.10 & 0.43 & 3.03 \\
\hline
\end{tabular}

The trophic level of 86 stations, are defined according to the bioindication scale and to the IBMR index, the normalized French macrophytes based index (AFNOR 2003, Haury et al. 2006) ; the corresponding conservation status is then calculated at all the stations. The average index per 'trophic' community is given in Table 4 . There is a relatively good adequacy between the trophic level founded on the plant communities and the IBMR. The high correlation between IBMR and conservation index confirms the trophic level as a key factor of the conservation status (Fig. 4). However communities $\mathrm{B}$ and $\mathrm{C}$ have similar indices, IBMR and conservation status (Table 4). The species composition of these two communities is also very close (Carbiener et al. 1990). Groups D and E have also similar IBMR, but contrasted index of conservation status. In the group $\mathrm{D}$, the conservation status varies strongly from good to poor ( +3 to -2 , Fig. 4$)$, whereas group $\mathrm{E}$ and $\mathrm{F}$ present lower variations respectively from -0.7 to -2 and -1.6 to -3.3 . The group D has low or high specific richness (3-10 species), but with a high cover. The lowest values of conservation status of this group are mostly related to the presence of polluto-tolerant species, such as P. pectinatus or Ranunculus fluitans. In the groups $\mathrm{E}$ and $\mathrm{F}$, the variations of index seem to be related to the specific richness and cover percentage, all the other metrics being similar. 


\section{Discussion}

\section{Distribution of communities with regard of envi- ronmental factors}

Up to nine communities of hydrophytes were found in the Rhine fringe. This relative high number may be due to the high diversity of habitats created by the dynamics of the river (as shown by Bornette et al. 2001) in spite of hydraulic management (straightening and canalisation). The aquatic habitats of the Rhine fringe are characterized by a broad range of vegetation communities: from mesotrophic to eutrophic vegetation (Trémolières et al. 1993, Eglin et al. 1997). In the Rhine cut-off channels conditions, nutrient level was highly related to the connectivity because of the specific hydrological functioning of large rivers as shown in Rhône and Danube (Bornette et al. 1998, Bornette et al. 2001, Janauer \& Kum 1996). In river floodplain, the river main channel provides eutrophic waters to the lateral arms during connections (floods) and induces scouring effect due to flow velocity. Such condition may induce highest species richness in waterbodies (Bornette et al. 1998). In the Rhine waterbodies, the nutrient level is actually very low due to an improvement of water quality of the Rhine river (IKSR Rheinatlas 2001). However the growing vegetation remains eutrophic, with species such as Potamogeton pectinatus, $P$. nodosus, Ranunculus fluitans. The nutrient level of water bodies has to be related to the whole aquatic system (water-plant-sediment) (Carignan \& Kalff 1980, Moore et al. 1994). Many authors consider that the nutrient level is not a discriminant parameter in the macrophytes distribution because they consider only the water nutrient content, i.e. SRP soluble phosphorus (Demars \& Harper 2005). In fact macrophytes growth can depend on the bioavailabilty of both phosphorus as SRP and interstitial P (Carpenter \& Adams 1977, Carignan \& Kalff 1980). The change in macrophytes colonisation remains lower than change in nutrient content (hysteresis effect) (Kohler et al.1989, Debold 1997, Trémolières \& Szwab in press).

The disconnected sectors exhibited meso-oligotrophic waters and the growing vegetation is dominated by mesotrophic species such as Callitriche obtusangula, Berula erecta and Lemna trisulca. However, because of seepage from the Rhine river to the groundwater, the former lateral arms close to the Rhine river present meso-eutrophic waters, characterized by eutrophic species such as Ceratophyllum demersum, Potamogeton pectinatus or $P$. lucens and related phytosociological communities. In standing waters the MyriophylloNupharetum, a species-poor community, is growing in oligotrophic conditions, because of an exclusive groundwater supply of good quality: groundwater quality has been improved by feeding with waters which were purified during the transfer through the soil-root system of the alluvial forest (Sanchez et al. 1991, Sanchez \& Trémolières 2003).

The new areas opened by a recent reconnection (2002-2004) with the river are colonised by the exotic species Elodea nuttallii in eutrophic waters (Weber 2005, Bornet 2005). In fluvial hydrosystems, the connectivity and the related trophy factor appear therefore as discriminant factors in the distribution of communities and species (Bornette et al. 1998, 2001, Demars \& Harper 2005). These last authors attribute the major role of connectivity to the exchange and input of propagules into a network of connected rivers rather than to an increase of nutrient level. This contradiction could be attributed to a scale change of the analysis (at river level or channel level).

\section{Metrics analyses}

Positive values of the proposed index represent a good quality, negative values characterized a degraded state (Table 3). Two important metrics are the presence of rare species, indicating good status, and the presence of polluto-tolerant species, indicating a degraded status with high values of correlation with discriminant axis.

The specific richness and the cover percentage (or abundance of species) are inversely related, and together provided an idea of the opening of the habitat and the risk of colonisation by exotic species. High specific richness fails to be an indicator for a good conservation status, the best status being given by a medium richness (5-7 species). The conservation status is good where high cover corresponds to a large specific richness, whereas the same cover with a low richness corresponds to a poor to bad status. Moreover a high nutrient content in water ensures a high development of biomass linked to a low or a high specific richness. Amoros \& Bornette (2002), Amoros (in press) and Bornette et al.(1998) observed a higher diversity for an intermediate degree of connection, which corresponds to an intermediate level of trophy in the case of established vegetation.

Connection and trophy level (nutrient $\mathrm{P}$ and $\mathrm{N}$ content), are narrowly linked to the functioning of the Rhine floodplain (Trémolières et al. 1993, Eglin et al. 1997). Connected stretches are eutrophic to hypertrophic depending on the eutrophication of the river. Disconnected stretches fed by groundwater are mesotrophic, due to the seepage of the river waters through the banks or bed into the groundwater. High trophic level 
or strong connection to a high trophic level waterbody can relegate a site to a bad status. In our study, a high specific richness as a result of an increase of trophy level leads to a poor status. In fact species which grew in very nutrient -rich waters, are polluto-tolerant $P$. pectinatus and Ranunculus fluitans species (Haslam 1978, Janauer \& Dokulil 2006). They then become dominant and exclusive, and lead to a degraded status.

However, surperficial connection between a water body and river main channel cannot be reduced to the phenomenon of eutrophication. Such contributes to inputs of sediments and propagules (Combroux et al. 2001), which can enhance the specific richness or decrease it by scouring effect of overflow or input of turbid nutrient-rich waters (see also Bornette et al. 1998). By this way, it appears necessary to associate the assessment of conservation status with both connectivity and biological metrics (such as polluto-tolerant species) as a response to complex effects of connectivity.

\section{Conservation status of Rhine habitats}

The phytosociological surveys allowed us to establish a classification of the macrophytes based conservation status of watercourses along the Rhine fringe. On this basis we can propose stretches or water courses to preserve, restore or abandone.

The five aquatic natural habitat types whose conservation requires designation of Natura 2000 sites as regards to the Habitat Directive (92/43/EEC) are present in the Rhine fringe. However, the distribution of sites characterized by a majority of UE 3260 (running waters) and UE 3150 habitats (standing waters) is probably linked to the degradation and artificialisation of aquatic zones by hydraulics works of the river Rhine. These works removed the floods and isolated all the lateral arms. The scarcity of marsh habitats UE 3130 and UE 3270 is relative to the removal of floods and as a consequence, lowering of water fluctuations. They are exclusively located in the areas where floods still occur. These habitats persist in the Northern Alsace plain and on the artificial islands of the Rhine which are still flooded, and where the variations of water level can occur.

The aquatic habitats of the Rhine fringe are in a good to poor conservation status (Fig. 5). More than 32\% of the habitats exhibit a good status, and $34 \%$ a poor status. Habitats in a high to a good conservation status (respectively $2.1 \%$ and $21.5 \%$ of 619 stations) are in opposition to habitats in a bad conservation status (around 7\%). Along the Rhine French fringe, three sectors were distinguished from the south to the north. These sectors correspond to geomorphic zonation and degradation of many aquatic habitats (Fig. 5).

The Southern sector ranges from Neuf-Brisach to St Louis in the south of Alsace. It presents a lower density of water courses than the northern and central sectors that can be explained by the low groundwater level (around $7 \mathrm{~m}$ ) and the consequence of the canalisation of the Rhine. The groundwater sources are rare and water courses are often contaminated by village effluents, and thus become largely eutrophic. This sector is considered to be in poor to bad conservation status. One exception is the natural reserve of the "petite Camargue alsacienne", located in the more Southern area which still presents some habitats of "moderate" conservation status.

The central part of the plain (from Strasbourg to Neuf-Brisach) corresponds to the braided and anastomosed sector of the Rhine. It is characterized by a large network of phreatic streams, due to the proximity of the groundwater from the soil surface. This part included disconnected, temporarily connected by floods and connected sites. The trophic level which is linked to the degree of connection in our study case was reflected by the type of vegetation. Hydrological functioning is characterized by a specific distribution of communities. The disconnected mesotrophic sites which are colonized by the community of Myriophyllo Nupharetum with the relatively rare species Nymphea alba, are in a moderate to high conservation status. Temporarily connected sectors are dominated by the mesotrophic Callitrichetum obtusangulae community. The sites connected to eutrophic waters are characterized by two communities: an eutrophic community, Potamogetonetum pectinati which is in a poor conservation status and the hyper-eutrophic Ranunculetum fluitantis community which is in a bad conservation status. This latest community is observed in some disconnected sectors such as the drainage canal flowing along the Rhine river and more and less contaminated by the seepage of Rhine waters (Trémolières et al. 1993). This sector is characterized by a high diversity of habitats related to a diversity of modalities of connection and thus of different conservation status.

The Northern sector from Strasbourg to Lauterbourg, is characterized by waters flowing from the Northern Vosges (Moder, Sauer, Lauter) into the Rhine. It corresponds to a sector of anastomoses and the beginning of a meandering river. These waters are neutral, lowly mineralized and often highly eutrophicated, they are mixed with phreatic waters in the plain. The Rhine habitats of this sector are in good to poor status. The poor status dominates, due to a high level of trophy and a decrease of flow, compared with the previous sector. 
Some waterbodies become shallow with muddy substrate. Under these conditions, water temperature which is not buffered by groundwater inputs, varies with the air temperature and is highly increased during summer. High temperature has a degrading effect on aquatic habitats (Welsh et al. 1998).

\section{Comparison with other biological methods}

The comparison between two indices in the Ill system shows that the index IBMR related to the trophy level is also linked to the conservation status. However the within-community and between-community variations of IBMR are relatively regular whereas we observe a gap between communities of the conservation index along the trophic gradient. The meso-eutrophic group D has low or high specific richness (3-10 species), but a high cover, which can explain higher variations of the conservation index. The lowest values of conservation status of this group are mostly related to the presence of polluto-tolerant species, such as $P$ pectinatus or Ranunculus fluitans. In the more eutrophic groups $\mathrm{E}$ and $\mathrm{F}$, the variations of index seem to be related to the specific richness and cover percentage, all the other metrics being similar.

The presence of rare species, such as Potamogeton coloratus due to the scarcity of the oligotrophic habitats, is also a determinant metric although they are species from species-poor habitats (Carbiener et al. 1990). In another way, the presence of polluto-tolerant species deteriorates the conservation status. Commonly a high specific richness was recognized as an indicator of good ecosystem functioning. In our study case it seems not to be a good indicator of conservation status as well in the Rhine sector as the ILL system. We show that at highest trophic level, there are high variations of specific diversity often related to a high level of disturbance (high connectivity, see Bornette et al. 1998, Bornette et al. 2001). Amoros et al. (2000) showed that these two phenomenons, nutrient tolerance and disturbance, can interfere in some cases. An example is the oligotrophic species $P$. coloratus which is tolerant to physical disturbances, that is why this species could survive in connected sectors but under nutrient - low conditions.

\section{Concluding remarks}

The proposed index of the conservation status of aquatic habitats was founded on both physical and biological metrics. The metrics proposed have to be simple for users. Due to the context of numerous cut-off channels after the canalisation of the river Rhine and the demand of restoration by reconnection to the main course, the connectivity was integrated as a metric of change in hydrological functioning of the fluvial hydrosystems, and indicator of reversibility. The connection contributes to inputs of nutrient-rich waters, fine sediments, and propagules. The trophic level a metric mostly related to connection in this study case, highly influences the conservation status. The biological response to different degrees of connectivity consists in a change in specific richness and occurrence of exotic and rare species. Superficial connectivity modifies specific richness, by changing propagules pool and favouring the propagation of exotic species. High connection if it is related to a high trophic level combined with absence of rare species and presence of exotic species leads to a poor or bad conservation status. In cases where high connection was linked to low nutrient input with oligotrophic rare species, the conservation status is good to high.

The upper Rhine floodplain seems to be a particular case of good adequacy between hydrological functioning (connectivity), trophic level and conservation status. This relationship between connection and trophy explains the relative good correspondence between the trophic index IBMR, and the index of conservation status in the case of the ILL fluvial system. The objective of determination of conservation status concerns potential for restoration, and consequently reversibility depending on succession stage of terrestrialization of aquatic systems. According to this study, the question is whether preservation of hydrological dynamics (by connection to the river) which favour disturbances, but also often inputs of nutrient-rich waters could be a guarantee of maintenance of communities of interest and of their diversity.

\section{Acknowledgements}

This work was supported by the LIFE "Rhin Vivant" coordinated by Region Alsace.

Thanks also go to two anonymous referees for improving a previous version of the paper and to JM Walter for controlling the last version.

\section{References}

AFNOR 2003. - Qualité de l'eau : Détermination de l'indice biologique macrophytique en rivière IBMR. Norme française NF T90-395.

Amoros C., Bornette G. \& Henry C.P. 2000. - A vegetation based method for ecological diagnosis of riverine wetlands. Environ. Manage., 25, 211-227.

Amoros C. \& Bornette G. 2002. - Connectivity and biocomplexity in waterbodies of riverine floodplains. Freshwat. Biol., 47, 761-776. 
Amoros C. in press. - La biodiversité dans les anciens chenaux des cours d'eau : patrons et processus. In Proceedings of floodplain symposium, Strasbourg, July 2002. Trémolières M. \& Schnitzler A. (eds) Tec\&doc Lavoisier.

Barrett S.C.H., Echert C.G. \& Husband B.C. 1993. - Evolutionary processes in aquatic plants populations. Aquat. Bot., 44, 105-145.

Bensettiti F., Gaudillat V., Haury J., 2002. - " Cahiers d'habitats ” Natura 2000. Connaissance et gestion des habitats et des espèces d'intérêt communautaire. Habitats humides. MATE/MAP/MNHN. Éd. La Documentation française, Paris. Tome 3, 457 p.+ cédérom.

Bornet A. 2005. Dynamique de colonisation de plantes invasives : les élodées dans la plaine d'Alsace. Mémoire de DEA ULP et de fin d'études ENGEES/CEVH. 58 p.

Bornette G., Amoros C., Lamouroux N. 1998. - Aquatic plant diversity in riverine wetlands: the role of connectivity. Freshwat. Biol., $39,267-283$

Bornette G., Piégay H., Citerio A., Amoros A. \& Godreau V. 2001. Aquatic plant diversity in four river floodplains: a comparison at two hierarchical levels. Biodivers. Conserv., 10, 1683-1701.

Braun-Blanquet J. 1964. - Pflanzensoziologie Grundzüge der Vegetationskunde. Springer, Wien, New York, 875p.

Carbiener R., Trémolières M., Mercier J.L. \& Orstcheit A. 1990. Aquatic macrophyte communities as bioindicators of eutrophication in calcareous oligosaprobe stream waters (Upper Rhine plain, Alsace). Vegetatio, 86, 71-88.

Carignan R \& Kalff J. 1980. - Phosphorus sources for aquatic weeds: water or sediments? Science, 207, 987-989.

Carpenter S.R. \& Adams S.A. 1977. - The macrophyte tissue nutrient pool of hardwater eutrophic lakes: implication for macrophyte harvesting. Aquat. Bot., 3, 239-255.

Combroux I., Bornette, G., Willby, N.J. \& Amoros C. 2001. - Regenerative strategies of aquatic plants in disturbed habitats: the role of the propagule bank. Archi. Hydrobiol.,152, 215-235.

Debold F. 1997. - Bioindication de la qualité des eaux courantes par les macrophytes aquatiques. Etude d'un cas d'amélioration de la qualité de l'eau et de ses conséquences sur la végétation: La Zembs en Alsace. Mémoire de diplôme d'état de docteur en pharmacie, ULP Strasbourg ,74 p.

Demars B.O.L. \& Harper D.M. 2005. - Distribution of aquatic vascular plants in lowland rivers: separating the effects of local environmental conditions, longitudinal connectivity and river basin isolation. Freshwater Biol., 50, 418-437.

Dodkins I., Ripey B. \& Hale P. 2005. - An application of canonical correspondence analysis for developing ecological quality assessment metrics for river macrophytes. Freshwater Biol., 50, 891-904.

Eglin I., Robach F \& Trémolières M., 1997. - Macrophyte biological methods used in the study of exchange between the Rhine river and the groundwater. Water Res., 31 (3), 503-514.

Garbey C., Thiébaut G., Muller S. 2003. - Morphological plasticity of a spreading aquatic macrophyte, Ranunculus peltatus, in response to environmental variables. Plant Ecol., 173, 125-137.

Grasmück N., Haury J., Léglize L. \& Muller S. 1995. - Assessment of the bioindicator capacity of aquatic macrophytes using multivariate analysis. Hydrobiologia, 300-301, 115-122.

Greenacre, M. J. 1984. - Theory and Applications of Correspondence Analysis. Academic Press, London, 364 p.

Hand, D. J. 1981. - Discrimination and Classification. Ed. Wiley, London. , 218 p.

Haslam S. 1978. - River plants. Cambridge University press, 396p.

Haslam S. 1982. - A proposed method for monitoring river pollution using macrophytes. Environ. Technol. Letters, 3, 19-34.
Haury J., Peltre M.C., Trémolières M., Barbe J., Thiébaut G., Bernez I., Daniel H., Chatenet P., Haan-Archipoff G., Muller S.., Dutartre A., Laplace-Treyture C., Cazaubon A., Lambert-Servien E., 2006. A new method to assess water trophy and organic pollution: the Macrophyte Biological Index for Rivers (IBMR) - Application to different types of rivers and pollutions. Pages 153-158. In Developments in Hydrobiology: Macrophytes in aquatic ecosystems: from biology to management. Caffrey J.M., Dutartre A., Haury J., Murphy K.J. \& Wade P.M. (eds). Springer.

Holmes N.T.H. 1995. - Macrophytes for water and other quality assessments. Unpublished report to the national rivers authority anglian region Orton Goldhay, Peterborough PE2 OZR, UK.

Holmes N.T.H., Newman J.R., Dawson F.H., Chadd S., Rouen K.J. \& Sharp L. 1999. - Mean Trophic Rank: a Users Manual. R\&D Technical report, Environment Agency, Bristol.

Interagences (étude) 1993. - Etude bibliographique des méthodes biologiques d'évaluation de la qualité des eaux de surface continentales. IDE Environnement, Agences de l'eau, MEDD. 276p.

Janauer G. A. \& Kum G. 1996. - Macrophytes and floodplain water dynamics in the River Danube ecotone research region (Austria). Hydrobiologia, 340, 137 - 140.

Janauer G.A. \& Dokulil 2006. - Macrophytes and algae in running waters. In Biological monitoring of rivers. Ziglio G., Siligardi M. \& Flaim G. (eds). John Wiley \& sons Ltd.

Kohler A. \& Janauer G. 1995. - Zur Methodik der Untersuchung von aquatischen Makrophyten in Fließgewässern. In Handbuch Angewandte Limnologie. Steinberg Ch., Bernhardt H.\& Klapper H. (eds). Ecomed-Verlag.

Kohler A. 1975. - Makrophytische Wasserpflanzen als Bioindikatoren für Belastungen von Fliesswässer-Ökosystemen. Verh. Umweltschutz Sonderr., Umwelttag. 31, 127-139.

Kohler A., Warneck L. \& Zeltner G.H. 1989. - Veränderungen von Flora und Vegetation in den Kalkreichen Fliessgewässern der Friedberger Au von 1972-1982 unter veränderten Belastungsbedingungen. Arch. Hydrobiol., 803, 407-451.

Lacaze J.C. 1996. - L'eutrophisation des eaux marines et continentales. Ed Ellipses. 191p.

Mainstone C.P. \& Parr W., 2002. - Phosphorus in rivers - ecology and management. Sci Tot. Environ, 282-283, 25-47.

Moore B.C., Lafer J.E. \& Funk W.H 1994. - Influence of aquatic macrophytes on phosphorus and sediment porewater chemistry in a freshwater wetland. Aquat. Bot., 49, 137-148.

Oberdorfer E., 1992. - Süddeutsche Pflanzen-gesellschaften. Vol. 1. Fels- und Mauer gesellschaften, alpine Fluren, Wasser-, Verhandlungs- und Moorgesellschaften. Gustav Fischer Verlag Jena, Stuttgart, New-York.

Rattray M.R., William C.H., Brown J.M.H., 1991. - Sediment and water as sources of nitrogen and phosphorus for submerged rooted aquatic macrophytes. Aquat. Bot., 40, 225-237.

Robach F., Thiébaut G., Muller S. \& Trémolières M., 1996. A reference system for continental running waters: plant communities as bioindicators of increasing eutrophication in alkaline and acidic waters in north eastern France. Hydrobiologia, 340, 67-76.

Sánchez-Pérez J.M. \& Trémolières M. 2003. - Change in groundwater chemistry as a consequence of suppression of floods : the case of the Rhine floodplain. J. Hydrol., 270, 89-104.

Sánchez-Pérez J.M., Trémolières M., Schnitzler A., Carbiener R. 1991. - Evolution de la qualité physico-chimique des eaux de la frange superficielle de la nappe phréatique en fonction du cycle saisonnier et des stades de succession des forêts alluviales rhénanes. Acta Oecol., 12, 581-601. 
Schneider S. \& Melzer A., 2003. - The trophic index of macrophytes (TIM)- a new tool for indicating the trophic state of running waters. Internat. Rev. Hydrobiol., 88, 49-67.

Trémolières M. \& Szwab A. in press. - Distribution of aquatic macrophytes in the former channels according to the degree of connection to the Upper Rhine (Alsace, France). In Proceedings of floodplain symposium, Strasbourg, July 2002. Trémolières M \& Schnitzler A. (eds), Tec\&doc Lavoisier.

Trémolières M., Eglin I., Roeck U., Carbiener R., 1993. - The exchange process between river and groundwater in central Alsace (Eastern France). I. The case of the canalised river Rhine. Hydrobiologia, 254, 133-148.
Trémolières M., Roeck U., Klein J.P. \& Carbiener R. 1994. - The exchange process between river and groundwater on the central Alsace floodplain (Eastern France) : II. The case of a river with functional floodplain. Hydrobiologia, 273, 19-36.

Weber M. 2005. - Etude de l'impact des reconnexions d'anciens bras au Rhin sur la dynamique de colonisation d'espèces végétales invasives: cas des élodées. Mémoire ULP Strasbourg. 38p

Welch E.B., Jacoby J.M. \& May C.W. 1998. - Stream quality. Pages 69-94. In River Ecology and Management. Naiman R.L. \& Bilby R.E. (eds ). Springer Verlag. 